\title{
WAY TO ASSESS THE DEVELOPMENT OF MUNICIPAL TOURISM INFRASTRUCTURE
}

\author{
Svetlana Victorovna Stepanova ${ }^{1^{*}}$, Vladimir Ivanovich Shulepov ${ }^{2}$ \\ ${ }^{1}$ Institute of Economics of the Karelian Research Centre of the Russian Academy of Sciences, Russia \\ ${ }^{2}$ Volga State University of Technology, Russia
}

Tourism is becoming a key element in the development of the economy of states and regions. Well developed tourism infrastructure is an important determinant of tourism business that can provide a wide range of competitive tourist services, and use the tourist and recreational potential of municipalities and regions without damaging the environment. One of the functions of tourism infrastructure is to build up sufficient material, technical, resource and other conditions for the men's recovery and recreation as well as to meet the needs of the local population in tourism and recreation. Development and improvement of tourism infrastructure, including its all structural elements (accommodation infrastructure, food infrastructure, leisure and recreation infrastructure, infrastructure of tourist services) contributes to the competitiveness of municipalities on the market of tourism services while attracting and retaining human capital.

The objective of the research, the results of which are set forth in this article, addresses the development of a toolkit for assessing the development of municipal tourism infrastructure for diagnosing the territorial development imbalances in the context of municipalities. The work is based on the analysis of the Russian and foreign research literature on the problem under review.

The outcomes of the research have scientific and practical significance for scholars who research the issues of the development of regional tourism, public administrations, regional authorities, as well as for representatives of tourism business.

Key words: Assessment of the development of tourism infrastructure, Municipality, Tourism infrastructure, Index

\section{INTRODUCTION}

The development of tourism infrastructure that meets international standards is essential for dynamic growth of tourism business [1], [4], [10], [13], and [17] and for providing a wide range of competi-tive tourism services. Municipalities strive to use tourist and recreational potential of the territory without damaging the environment.

Serving the processes of developing, distributing and consuming tourist products, tourism infrastructure defines its qualitative, value, and cost characteristics, thus, determining the ultimate outcome of functioning and developing the regional tourism business[26]. It is worth emphasizing that tourism infrastructure meets not only the interests of domestic and international tourists, but also meets the needs of the local population in tourism and recreation [30], [31]. Tourism infrastructure creates necessary material, technical, resource and other conditions for the human's recovery and restoration, hence ensuring their recreation, enhancing the territory's economy owing to the multiplier effect.

Modern globalization trends, improving communications, increasing mobility, and increasing role of human capital have brought the issue of competition among territories, including municipalities at the regional level up to date. At the regional level, municipalities compete among themselves for attracting tourist and financial flows, as well as for human capital. In this regard, the assessment of the development of tourism infrastructure is crucial for identifying territorial imbalances in locating tourism infrastructure in the municipal context, defining pressure points' and developing recommendations for municipal and regional authorities and business community.

We should mention that the development of tourism infrastructure should not be an end in itself, but rather a qualitative change in the socioeconomic development of the territory to increase its competi-tiveness on the market [25].

There has been a positive trend in the growth of the number of research devoted to the development of the tourism industry in the regions of Russia. The tourism infrastructure is developing in many Russian regions, so the number of papers that analyze the current state, development dynamics, specific character and issues of functioning of tourism infrastructure of the regions is increasing [11], [12], [20], [28]. Scholars have proposed a number of author's definitions of tourism infrastructure, which encapsulate different approaches to its nature and structure [3], [4], [22], [23], [26]. The works on methodological approaches to assessing the development of the regional tourist infrastructure 
are of special interest [17], [19]. There have also been the studies that assess the development of tourism infrastructure by sociological methods from the viewpoint of the local population and visitors of the territory, including the Internet [15], [16], [29]. The relationship between the location of the tourism infrastructure and the recreational needs of the local population is best discussed in the works [21], [24]. We should note that most studies indicate the specific character and assess the development of tourism infrastructure as a whole in the region. While specific character of regional tourism, extensive differentiation of indexes, and the lack of a number of data at the municipal level make it difficult to apply the full range of proposed methods for assessing the development of tourism infrastructure in the municipal context. Works that assess the development of tourism infrastructure at the municipal level are less common [2], [5], [7], [8], [27]. The objective of this article is to propose a toolkit for assessing the development of municipal tourism infrastructure.

\section{PROBLEM STATEMENT AND METHODOLOGY}

The article suggests a methodical approach to assessing the development of municipal tourism infrastructure, which allows for identifying territorial imbalances of its location in the region, further developing recommendations for the improvement, in- cluding the alignment of investment projects in the tourism industry. The authors have also proposed the criteria for assessing the objects of structural elements of tourism infrastructure. The authors analyzed the terminology system, applied the analogy and index methods.

\section{RESULTS AND DISCUSSION}

\section{Ways to assess the development of tourism infrastructure}

The research literature reviews the set of indicators required to assess the development of the regional tourism infrastructure, which is stipulated by:

1. the variety of approaches to defining the 'tourism infrastructure';

2. the specific character of the development of tourist and recreational activities in the region;

3. a specific range of objects of tourist infrastructure in the regions;

4. the lack of reliable statistical data illustrating the structural elements of tourism infrastructure at the municipal level;

5. etc.

A number of approaches of Russian scholars to assess the development of tourism infrastructure at the level of regions and municipalities are given in Table 1.

Table 1: Way to assess the development of tourism infrastructure

\begin{tabular}{|c|c|c|c|c|}
\hline No. & Full name & Methods & Methodology & Advantage \\
\hline 1 & $\begin{array}{l}\text { Limonina I.G., } \\
2007 .\end{array}$ & $\begin{array}{l}\text { index method, } \\
\text { scoring method and } \\
\text { cluster analysis }\end{array}$ & $\begin{array}{c}\text { calculation of integral indicators } \\
\text { (indices) to obtain a nondimensional } \\
\text { index; calculation of score based on } \\
\text { the Bennett Method, and conduct- } \\
\text { ing cluster analysis. }\end{array}$ & $\begin{array}{l}\text { method allows for the } \\
\text { territorial groups } \\
\text { allocation }\end{array}$ \\
\hline 2 & $\begin{array}{c}\text { Velichkina A.V., } \\
2014 .\end{array}$ & index method & $\begin{array}{l}\text { calculation of the index of the } \\
\text { regional tourism infrastructure } \\
\text { based on indices for each structural } \\
\text { element of the tourism infrastructure }\end{array}$ & $\begin{array}{l}\text { sufficient number of } \\
\text { indicators reflecting the } \\
\text { state of the } \\
\text { structural elements of } \\
\text { the regional } \\
\text { tourism infrastructure }\end{array}$ \\
\hline 3 & $\begin{array}{c}\text { Popova O.B., } \\
\text { Podosenova I.A., } \\
2015 .\end{array}$ & index method & $\begin{array}{c}\text { calculation of the integrated } \\
\text { coefficient based on M.S.Chikinova } \\
\text { methodology }\end{array}$ & $\begin{array}{l}\text { illustrates an uneven } \\
\text { distribution of } \\
\text { tourism and } \\
\text { infrastructure } \\
\text { potential }\end{array}$ \\
\hline 4 & $\begin{array}{l}\text { Minaev V.A., } \\
\text { Ulyanchenko L.A., } \\
\text { Cyschuk E.A., } \\
2015 .\end{array}$ & $\begin{array}{l}\text { scoring method, } \\
\text { which reflects the } \\
\text { quantitative } \\
\text { significance of } \\
\text { specific qualitative } \\
\text { indicators }\end{array}$ & $\begin{array}{l}\text { the algorithm for processing the } \\
\text { expert information and interpreting } \\
\text { the ranking of the scoring } \\
\text { characteristics that reflect the state } \\
\text { of municipal tourism infrastructure. } \\
\text { Scores are of an evaluation } \\
\text { character }\end{array}$ & $\begin{array}{l}\text { the approach allows for } \\
\text { quantifying the differ- } \\
\text { ence of } \\
\text { municipalities, and } \\
\text { cumulatively comparing } \\
\text { them on the quality of } \\
\text { the infrastructure }\end{array}$ \\
\hline
\end{tabular}


While there are clear advantages of the approaches to assess the development of tourism infrastructure, we would indicate the following as constraints of these approaches' application. The constraints in the use of the method proposed by Limonina I.G. [7] is the choice of a limited number of indicators, while the choice of a wider set of indicators will make it difficult to allocate territorial groups. The approach proposed by Velichkina A.V. [19] looks simple at the regional level, but its use at the municipal level is complicated by the set of indicators used. The methodology suggested by Popova O.B. and Podo-senova I.A. [27] uses the set of indicators, which is limited, thus, a number of significant indicators are neglected. The approach proposed by Minaev V.A., Ulyanchenko L.A., Tsyschuk E.A., [8] implies a quantitative (scoring) assessment based on expert procedures. However, the lack of a step-by-step instruction for assigning scores on the basis of expertise hampers this methodology application.

The scholars indicate that the composition of the structural elements of tourism infrastructure is dependent on the context of tourist activity, which is determined by the influence of the factors both directly related to tourism (tourist resources, travel goals and motives, the structure of the population's incomes, etc.), and not related to tourism (development of transport, trade, etc.) [26]. For instance, the unique potential of the cold White Sea favored the opening of two diving centers while there are no beaches on the coast of the Republic of Karelia.

However, an objective (ideal) assessment of the development of municipal tourism infrastructure can be conducted based on a combination of not only quantitative but also qualitative indicators. To determine the level of development of tourism infrastructure, the authors proposed criteria for assessing the objects of tourism infrastructure that characterize the aspects crucial for their functioning:
1. state of the object: the quantitative characteristics of the object, depending on its functionality; proper facilities of neighboring territories;

2. availability: accessibility of road transport (including public transport); parking; access opportunities for people with disabilities; convenience of work;

3. service: service in foreign languages (English and the language of the neighboring state); informative signs and information in foreign languages; cashfree payments;

4. information: information boards; information stands; information posted on the Internet;

5. location: distance from/to significant destinations.

The proposed evaluation criteria are universal for almost all objects of the structural elements of tourism infrastructure: the infrastructure of accommodation, food infrastructure, leisure and recreation infrastructure, tourism services infrastructure.

Among these criteria we should focus on marketing promotion of the possibilities of the territory. The improvement of communications, the growth of living standards and the level of education of the population, makes the problems of promoting the possibilities of the territory on the Internet relevant [2], [3].

Qualitative assessments not only by the expert community, but also by local residents and visitors of the territory, are importance in identifying potential growth zones and problem areas for the development of municipal tourism infrastructure [15], [16].

\section{ASSESSMENT OF THE DEVELOPMENT OF MUNICIPAL TOURISM INFRASTRUCTURE}

Assessment of the development of municipal tourism infrastructure is proposed based on the calculation of the integrated indicator (Table 2).

Table 2: Methodology for assessing the development of municipal tourism infrastructure

\begin{tabular}{|c|c|c|}
\hline No. & Calculation formula & Explanations \\
\hline 1 & $i_{d j}=\frac{F_{d j}}{m}$ & $\begin{array}{c}\boldsymbol{i}_{d j} \text { - index of the } \boldsymbol{j} \text {-th indicator of the } \boldsymbol{d} \text {-th regional municipality } \\
\boldsymbol{F}_{d j} \text { - actual } \boldsymbol{j} \text { - } \boldsymbol{t} \text { indicator of the } \boldsymbol{d} \text {-th regional municipality } \\
\boldsymbol{m}_{j} \text { - median of the } \boldsymbol{j} \text {-th indicator of the regional municipality }\end{array}$ \\
\hline 2 & $I_{d k}=\frac{1}{x} \cdot \sum_{j=1}^{\wedge} i_{d j}$ & $\begin{array}{r}I_{d k}-\text { indicator of development of the } \boldsymbol{k} \text {-th structural element of tourism } \\
\text { infrastructure of the } \boldsymbol{d} \text {-th regional municipality } \\
x \text {-the number of selected indicators of the structural element of tourism } \\
\text { infrastructure }\end{array}$ \\
\hline 3 & $I_{d}=\frac{1}{n} \cdot \sum_{k=1}^{n} i_{d k}$ & $\begin{array}{c}I_{d} \text { - региона an integral indicator of the level of development of tourism } \\
\text { infrastructure of the } \boldsymbol{d} \text {-th regional municipality } \\
n \text { - number of structural elements of tourism infrastructure }\end{array}$ \\
\hline
\end{tabular}


The methodology proposed is based on allocating a set of indicators that demonstrate essential and qualitative characteristics of functioning of the elements of tourism infrastructure, by the values of which one can judge the level of development of these elements and tourism infrastructure in the municipality as a whole [10], [14].

The authors suggest the following elements as the structural elements of tourism infrastructure, based on the importance of their functions: accommodation infrastructure, food infrastructure, leisure and recreation infrastructure and infrastructure of tourist services. To assess the level of development of tour-ist infrastructure of the region in the municipal context, it reasonable and sufficient to select the following indicators, which characterize the qualitative aspects of functioning of infrastructure's structural elements (Table 3 ).

Table 3: Assessment indicators of municipal tourism infrastructure by structural elements

\begin{tabular}{|c|c|c|}
\hline No. & Structural element & Indicators \\
\hline 1 & $\begin{array}{c}\text { Accommodation infra- } \\
\text { structure }\end{array}$ & $\begin{array}{l}\text {-number of accommodation facilities (units); } \\
\text {-number of places available in the facilities (units); } \\
\text {-number of places in auto-camping (units); } \\
\text {-number of sanatoria (units); } \\
\text {-number of places available in sanatoria (units). }\end{array}$ \\
\hline 2 & $\begin{array}{l}\text { Leisure and Recreation } \\
\text { infra-structure }\end{array}$ & $\begin{array}{l}\text {-number of restaurants, cafes, bars (units); } \\
\text {-number of places in restaurants, cafes and bars (units); } \\
\text {-number of local enterprises (units). }\end{array}$ \\
\hline 3 & $\begin{array}{c}\text { Infrastructure of Tourist } \\
\text { Services }\end{array}$ & $\begin{array}{l}\text {-objects of cultural and educational tourism: the number of museums, exhibition } \\
\text { halls, etc., the number of souvenir and specific products available for visiting, } \\
\text { etc. (units); } \\
\text {-active tourism facilities: number of yacht clubs, ski and horse riding centers, } \\
\text { water parks, etc. (units); } \\
\text {-objects for tourist shopping: the number of shopping and entertainment centers, } \\
\text { souvenir shops, etc. (units); } \\
\text {-objects of religious and cultural tourism: the number of religious objects of vari- } \\
\text { ous faiths (units); } \\
\text {-ecotourism facilities: the number of protected natural areas and visit centers, } \\
\text { the number of equipped beaches and ecological trails, the num-ber of parks and } \\
\text { recreation areas, etc. (units); } \\
\text {-other types of tourism. }\end{array}$ \\
\hline 4 & $\begin{array}{c}\text { Infrastructure of Tourist } \\
\text { Services }\end{array}$ & $\begin{array}{l}\text {-number of tour operators registered in the territory of the municipality (units); } \\
\text {-number of tourist organizations that sell tourist services on the territory of the } \\
\text { municipality (units); } \\
\text {-number of information and tourist centers (units); } \\
\text {-number of tours offered on the territory of the municipality (units). }\end{array}$ \\
\hline
\end{tabular}

It is reasonable to assess the development of leisure and recreation infrastructure owing to the spe-cific characterizes of the territory, thus, it will allow for neglecting important for the municipality tourist and recreational activities and the objects of tourist infrastructure. In this regard, the composition of the indicators of this element of tourism infrastructure is the most variable.

The difference between the method proposed for assessing the development of municipal tourist infrastructure from the previously discussed ones is as follows:
1. it uses median indicators which allows to correlate the level of development of the relevant structural elements and tourist infrastructure in general with the average value (median) for the region: if the index and the indicator are above 'one', then the level of development is above the average for the region, if these are below 'one', then the level is below the regional level, if the index is equal to 'one', this means that the level of development corresponds to the regional level; 
1. it employs a set of indicators this ensuring a comprehensive assessment of the development of structural elements and municipal tourism infrastructure as a whole;

2. it makes possible to adjust the set of indicators in accordance with the specific character of the development of tourist and recreational activity at the level of municipalities and the region as a whole.

However, we should indicate that the assessment of the level of development of tourism infra-structure based on the proposed indicators is an aggregate complex indicator that to some extent balances certain features and possible competitive advantages of specific municipalities. A more detailed assess-ment in the context of certain types of tourism (for example, ecological, active and other types of tour-ism), according to the proposed methodology, will help avoid this limitation, and assess the real level of development of the tourist infrastructure, taking into account the specific features of municipality.

It is worthwhile mentioning that globalization trends, improvement of communication, increased mobility, and the increasing role of human capital have made the issue of competition among territories, including municipalities at the regional level negotiable. Tourist infrastructure is a part of the territorial infrastructure framework, without balanced development of the latter, it is not possible to manage tourism and recreational activities. The development of transport and energy infrastructure is of particular impor-tance, as they link together all other kinds of infrastructure [1], [5], [10].

\section{CONCLUSION}

Sophisticated tourism infrastructure is crucial for providing a wide range of competitive tourist services and functioning of municipal tourist business and a region as a whole. To make tourism infra-structure function on a proper way it is essential to build up material, technical, resource and other condi-tions for the men's recovery and recreation, while meeting the needs of the local population in tourism and recreation. Development of all structural elements of tourism infrastructure, i.e. accommodation in-frastructure, food infrastructure, leisure and recreation infrastructure and infrastructure of tourist services is important for municipalities and the region as a whole. Development and improvement of tourism in-frastructure, including its all structural elements, helps increase the competitiveness of municipalities on the market of tourism services, while attracting and retaining human capital.

The paper proposes the criteria for assessing the objects of structural elements of tourism infra-structure that characterize important aspects of objects' functioning. The article suggests a methodical approach to assessing the development of municipal tourism infrastructure, which allows for identifying territorial imbalances of its location in the context of municipalities. Based on the identified 'pressure points', the authors proposed recommenda- tions for local authorities, and business community on how to develop and improve individual structural elements and tourism infrastructure in general. Overcoming the obstacles of improving tourist infrastructure requires an integrated approach from the side of regional and municipal authorities who should take into account the interests of business and local population. It is worthwhile mentioning that the regional infrastructure framework as a whole, including transport, energy and other types of infrastructures should also be on the high level of development.

\section{REFERENCES}

1. Balitskiy, S., Bilan, Y., \& Strielkowski, W. 2014. Energy security and economic growth in the European Union // Journal of Security \& Sustainability Issues, Vol. 4, No. 2, pp. 125-132.

2. Blešic, I., Tešanovi'c, D., Psodorov, D. (2011). Consumer satisfaction and quality ' management in the hospitality industry in South-East Europe. African Journal of Business Management, 5(4), 1388-1396

3. Chiabai, A., Platt, S., Strielkowski, W. 2014. Eliciting users' preferences for cultural heritage and tourism-related e-services: a tale of three European cities // Tourism Economics, Vol. 20, No. 2, pp. 263277. doi: $10.5367 /$ te. 2013.0290

4. Jovanović S., llić I. Infrastructure as important determinant of tourism development in the countries of Southeast Europe // Ecoforum. [Volume 5, Issue 1 (8), 2016 . P. 288-293.

5. Kałamucka, W., Kałamucki, K. Touristic infrastructure of municipalities in the border section of Bug valley's Dołhobyczów-Włodawa in the context of existing protected areas // Annales - Universitatis Mariae Curie-Sklodowska, Sectio B, 2011. No. 66(2). P. 103-119. DOI: 10.2478/v10066-011-0016-X

6. Kumar A. Existing Tourism Infrastructure and Services in Lahaul Valley of Himachal Pradesh: A Case Study of Hotels / Guest Houses, Home Stays and Travel Agencies // Amity Research Journal of Tourism, Aviation and Hospitality Vol. 01, issue 01, January-June 2016. P. 71-76.

7. Limonina, I.G. Territorial differences of tourist infrastructure potential development in the Leningrad region // Vestnik of Saint Petersburg University. 2007. Volume 7. Issue. 2. P. 117-127.

8. Minaev, V.A., Ulyanchenko, L.A., Cyschuk E.A. Evaluation of tourist resources and tourism in-frastructure quality in municipalities // Scientific Journal Universities for Tourism and Service As-sociation Bulletin. 2015. Vol. 9. No.3. P. 4-13.

9. Narkūnienè, R., Gražulis, V., A rbidane, I. Tourism development conditions in the municipalities of Lithuania and Latvia regions // SBU International Conference Proceedings. 2017. Vol. 5. P. 320-325. DOI: http://dx.doi.org/10.12955/cbup.v5.945 
10. Pykhov P.A., Kashina T.O. Infrastructure security of the URAL regions: assessement technigue and diagnostic results // Economy of region, 2015. No. 3. P. 66-77

11. Sever, D. Development Harmonisation of Mountain Resorts Ropeway and Tourist Infrastructures in the Republic of Slovenia // Promet- Traffic- Traffico. 2000. Vol. 12. No.2. P. 121-126.

12. Shulepov V.I., Stepanova S.V. Tourist direction of cross-border regions development of Russia // Journal of Applied Engineering Science, no. 3, Volume 15, year 2017.. P. 323-328. DOI:10.5937/jaes1512333

13. Stepanova S.V. Development of tourist infrastructure in the northern border regions of Russia.// Problems of territory's development. 2015 no. 6. P. 214-225.

14. Stepanova, S.V. General Trends and Features of Tourism Infrastructure Development in Russia's Regions // Moscow University Economics Bulletin, 2016, no 3, P. 68-84.

15. Tabaku E., Cerri S. An assessment of service quality and customer satisfaction in the hotel sector // Tourism and Hospitality Industry. 2016, Congress Proceedings, P. 480-489.

16. Tampakis S., Manolas E., Tampakis V. Assessing tourist infrastructure in the island OF Skiathos: the views of locals and visitors // Tourismos: an international multidisciplinary journal of tourism Volume 7 , Number 1, Spring-Summer 2012, pp. 175-191

17. Tappaskhanova E., Mustafaeva Z. A., Tokmakova R. A., Kudasheva M. Z. Region Tourist and Recreation Complex Development // Economy of region, 2015. № 2 (42). C. 208-219. doi 10.17059/2015-2-17

18. The attractiveness of rural tourism destinations in the Republic of Karelia and Eastern Finland Karhapää-Puhakka S., Suni Ja. (eds.). Joensuu, 2014 №1.p. 81

19. Velichkina, A.V. The assessment of the regional tourism infrastructure development // Economic and Social Changes: Facts, Trends, Forecast. 2014. № 2. C. $193-202$.

20. Wu H.C., Ko, Y.J. Assessment of Service Quality in the Hotel Industry // Journal of Quality As-surance in Hospitality \& Tourism. 2013. № 14. P. 218-244.

21. Zherdev N.V. Razmeshchenie turistskoi infrastruktury i formirovanie rekreatsionnykh potrebnostei naseleniya (na primere Kurskoi oblasti) [Placing of tourist infrastructure and formation of recreational needs of the population (case study of the Kursk Oblast]. Uchenye zapiski: elektronnyi nauchnyi zhurnal Kurskogo gosudarstvennogo universiteta [Scientific notes: the online academic journal of Kursk State University], 2013, No.2(26). P229-316

22. Kosmanev A. L. Turistskaya infrastruktura $v$ regional'nykh issledovaniyakh [Tourist infrastructure in regional studies]. Vestnik VGU, Seriya: geografiya. Geoekologiya [Proceedings of Voronezh State University. Series: geography. geoecology], 2012, no. 2 , pp. 5-12.

23. Lazarev V. A. Cushchnostnoe soderzhanie ponyatii "infrastruktura turizma" i "industriya turizma" [Essential content of the concepts "tourist infrastructure" and "tourist industry"]. Izvestiya UrGEU [Izvestia of the USUE], 2012, no. 1 (39), pp. 38-41.

24. Martyshenko N. S. Turistskii potentsial Primorskogo kraya i perspektivy razvitiya turistskoi industrii na ego territorii [Tourist potential of Primorsky Krai and prospects of tourist industry de-velopment on its territory]. Narodnoe khozyaistvo. Voprosy innovatsionnogo razvitiya [National economy. Issues of innovative development.], 2011, no. 1, pp. 74-88.

25. Mezhevich N.M. Infrastrukturniy factor v sovremennoi ekonomicheskoi geografii makroregiona "Sever-Zapad" [Infrastructural factor in modern economic macro regional geography "North-West"]. // Pskovsky regionalniy zhrnal [Pskov regional journal], 2013, No.16, pp. 6-11. 2013. № 16. C. 3-11.

26. Pogorelova N. V. Teoreticheskie podkhody k issledovaniyu ponyatiya "turistskaya infrastruktura" [Theoretical approaches to the study of the concept "tourist infrastructure"]. Problemy sovremennoi ekonomiki [Problems of modern economics], 2011, no. 5, pp. 57-61.

27. Popova O.B. Toristsko-infrastrukturniy potentsial Orenburgskoi oblasti [Tourist-infrastructural potential of the Orenburg Oblast]. // Vestnik Orenburgskogo gosudarstennogo universteta [Vest-nik of Orenburg State University], 2015. No.1 (176). Pp. 167-173.

28. Strielkowski, W., Promoting tourism destination through film-induced tourism: The case of Japan // Trziste 29(2), 2017 pp. 193-203.

29. Bilan, Y. Strielkowski, W. Karbach, R. Mentel, G. Secure development of country and competi-tiveness issues: Case of germany's energy security // Journal of Security and Sustainability Issues, 2017, 6(3), pp. 329-342

30. Strielkowski, W. Šperková, L. Jacek, B. Migration and remittances nexus: Economic implications and analysis // Amfiteatru Economic 19(46), 2017, pp. 771-789

31. Radovic, D. Strielkowski, W. Rausser, G. Wang, J. Cepei, M. Economic analysis of sustainable tourism: A case study of Nottingham // Transformations in Business and Economics, 2017, 16(2B), pp. 703-714

Paper submitted: 05.04.2018.

Paper accepted: 26.11.2018.

This is an open access article distributed under the CC BY-NC-ND 4.0 terms and conditions. 